\title{
PERAN ORANG TUA DALAM MENGEMABNGKAN KARAKTER ANAK PENDERITA ADHD (Attention Deficit Hperactivity Disorder)
}

\author{
Dita Elha Rimah Dani, Ichsan \\ UIN Sunan Kalijaga Yogyakarta \\ e-mail: ditaclouds24@gmail.com , Ichsandjalal@gmail.com
}

\begin{abstract}
In terms of developing children with ADHD for parents, it is an easy thing, especially from the character who is hyperactive (difficult to control movement), intense (difficult to control thoughts), impulsivity (difficulty resisting desire). In addition, there are several factors of children with $A D H D$, namely heredity, brain function factors and environmental factors. Many things can be done by parents in helping develop the character of children with sufferers, including maintaining health and controlling emotions in dealing with the child and teaching in choosing friends who are the same as physically. And the method used in this research is qualitative with descriptive phenomenology, By using the approach of observation, interviews and documentation.
\end{abstract}

Keywords: Character, ADHD, The Role Of Parents

\begin{abstract}
ABSTRAK
Dalam hal mengembangkan karakter anak penderita ADHD bagi orang tua bukanlah suatu hal yang mudah, terlebih dari karakter yang terlalu hiperaktif (sulit mengendalikan gerakan), intensi (sulit memusatkan perhatian), impulsivitas (sulit Menahan keinginan). Selain itu terdapat beberapa faktor dari penderita anak ADHD yaitu bisa faktor dari genetic (keturunan), faktor fungsi otak dan juga faktor lingkungan. Banyak hal yang dapat dilakukan oleh orang tua dalam berperan mengembangkan karakter anak penderita diantara melalui menjaga Kesehatan dan lebih mengontrol emosi dalam menghadapi anak anak tersebut dan mengajarkan dalam hal memilih teman-teman yang sama seperti fisiknya.serta metode yang digunakan dalam penelitian ini adalah Kualitatif dengan fenomenologi deskriptif, Dengan menggunakan pendekatan Observasi, wawancara dan dokumentasi.
\end{abstract}

Kata kunci : Karakter, ADHD, Peran Orang Tua

\section{PENDAHULUAN}

ADHD (Attention Deficit Hperactivity Disorder) merupakan salaah satu kondisi berkebutuhan khusus yang termasuk dalam gangguan perilaku. Jenis kebutuhan khusus ini adalah gangguan di mana perkembangan dalam peningkatan aktivitas motorik anakanak yang dimana menyebabkan anak-anak cenderung melakukan aktivitas secara berlebihan. Prevalensi ADHD pada anak usia sekolah dasar di Indonesia secara umum belum diketahui secara pasti. ${ }^{1}$ Adapun berdasarkan penelitian terbaru yang dilakukan

\footnotetext{
${ }^{1}$ Baihaqi, M \& Sugiarman, M. Memahami dan membantu anak ADHD. (Bandung: PT Refika Aditama, 2006)
} 
pada tahun 2016 yaitu terdapat 8,09\% anak dengan penderita ADHD yang berada di Kota Yogyakarta dan Kabupaten Sleman. ${ }^{2}$ Gejalan anak penderita ADHD meliputi hiperaktif yang berlebihan, kurang perhatian dan tidak impulsive, beberapa faktor yang menyebabkan anak hiperaktif yaitu faktor neurologi, terjadinya perkembangan otak yang lambat, faktor toksik, faktor genetik, faktor psikososial, dan lingkungan serta peran orang tua. ${ }^{3}$ Kondisi anak ADHD seringkali membuat orang kurang sabar, jengkel dan merasa putus asa (Hidayati, 2013). ${ }^{4}$

Karakteristik yang terdapat pada anak ADHD Attention Defisit Hperactivity Disorder) yang utama yaitu: a. Inatensi (kesulitan meusatkan perhatian, b. Impulsivitas (kesulitan menahan keinginan), c. Hiperaktivitas (kesulitan mengendalikan gerakan. ${ }^{5}$ Selain terdapat karakter ternyata yang perlu diketahui anak ADHD juga memiliki problem, dimana problem tersebut dibedakan menjadi dua yaitu masalah disekolah dan masalah dirumah. Dimana masalah yang sering terjadi dirumah meliputi: lebih mudah cemas dan mengalami gangguan psikomotorik, cenderung keras kepala dan mudah marah bila keinginannya tidak terpenuhi. Hambatan-hambatan tersebut membuat anak menjadi kurang mampu menyesuaikan diri dengan lingkungannya. Anak dipandang nakal dan tidak jarang mengalami penolakan/ejekan baik itu dari keluarga maupun lingkungan teman-temannya. Peran dari orang tua menjadi faktor yang sangat menentukan. Apabila ditinjau dari segi keluarga penderita, maka aadanya seorang anak yang menderita kelainan perkembangan bisa menjadi beban bagi orang tuanya. Lebih banyak waktu dan perhatian harus lebih banyak diberikan kepada anak tersebut.

Bahwa efektivitas sebagai penanganan untuk anak yang berkebutuhan khusus lebih banyak ditentukan oleh peran orang tua serta dukungan dari keluarga dan orang terdekat lainnya. Dukungan dan penerimaan dari keluarga dan orang terdekat dapat memberi energi dan kepercayaan dalam diri anak tersebut. Mengembangkan karakteristik pada anak ADHD itu bukan hal yang mudah untuk dilakukan, oleh karena itu dalam penanganannya peran dari orang tua sangat penting terutama dalam hal segi perhatian,

\footnotetext{
${ }^{2}$ Wimbarti S \& Rahmi, I.Inhibition in ADHD and non-ADHD children ages 6-12 years. Internationl Journal of Research Studies in Psychology, Vol. 7, No.(1), 2018

${ }^{3}$ John W. Santrock. Perkembangan Anak, Jilid 2. (Jakarta: Erlangga. 2007), hlm. 257

${ }^{4}$ Hidayati, E.Peran pendampingan regulasi emosi terhadap perilaku maltreatment pada ibu dari anak $G P P / H$. Jurnal Humanitas. 2013

59 A. Dayu P, Mendidik Anak ADHD . (Jogjakarta: Javalitera, 2014). hlm.38-39
} 
memahami dan menjalani kehidupan yang khusus dibandingkan dengan anak yang normal lainnya. ${ }^{6}$

Selain itu diperkuat oleh hasil penelitian Ratih DwiLestari Puji Utami, WahyuNingsi Safitri, Christiani Bumi Pangesti, dan Nur Rakhamawati. Pada penelitian ini pengalaman orang tua dalam merawat anak dengan ADHD (Attention Deficit Hyperactivity Disorder) dimana membahas pola asuh orang tua yang terdiri dari pola asuh otoriter dan permisif dikarenakan penderita ADHD memiliki keterbatasan untuk menentukan pilihannya sendiri sehingga pola asuh demokrastis tidak bisa diterapkan dan hambatan perawatan, dimana hambatan yang dilalui orang tua adalah perilaku tantrum anak, dan stigma negatif dari masyarakat. ${ }^{7}$ karakteristik anak kaitannya dengan peran orang tua dimana peran orang tua yang demokratis akan menghasilkan karakteristik anak yang mandiri, dapat mengontrol diri, mempunyai hubungan baik dengan teman, mampu menghadapi setres, mempunyai minat terhadap hal-hal yang baru, serta kooperatif terhadap orang lain. Peran orang tua yang otoriter akan menghasilkan karakter anak yang penakut, pendiam, tertutup, tidak berinsiatif dan gemar menantang, cemas dan suka menarik diri. Peran orang tua permasif akan menghasilkan karakter anak yang impulsif, agresif, tidak patuh, manja, kurang mandiri, kurang percaya dan kurang matang dalam secara sosial. Sedangkan peran orang tua penelantar akan menghasilkan karakteristik anak-anak yang moody, impulsive, agresif, kurang bertanggungjawab, tidak mau mengalah, self system (harga diri) yang rendah, sering bolos dan bermasalah dengan teman. Peran orang tua yang kurang tepat akan memberikan dampak seperti tidak taat aturan, kebiasaan buruk perilaku menyimpang, dan post playing delay. ${ }^{8}$ Berdasarkan fenomena yang terdapat di lapangan peneliti tertarik untuk melakukan penelitian tentang peran orang tua dalam mengembangkan karakter anak penderita ADHD (AttentionDeficit Hyperactivity Disorder). ${ }^{9}$ Tujuan penelitian untuk mendeskripsikan bagaimana peran orang tua dalam mengembangkan karakter anak ADHD dalam segi emosional dan sosial anak.

\footnotetext{
${ }^{6}$ MIF. Baihaqi. Memahami dan Membantu Anak ADHD. (Bandung: PT Refika Aditama, 2008), hlm. 71

${ }^{7}$ Ratih Dwilestari Puji Utami, Wahyuningsih Safitri, Christiani Bumi Pangesti3, \& Nur Rakhmawati. Pengalaman Orang Tua Dalam Merawat Anak Dengan Attetion Deficit Hyperectivity Disorder (ADHD). Jurnal Kesehatan Kusuma Husada. Vol. 12 No. (2), Juli 2021, hlm. 222-230

${ }^{8}$ Hibana S. Rahman, Op.Cit, hlm 95

${ }^{9}$ Ahmad Subandi \& Rusana, PENGALAMAN ORANG TUA DALAM MENGASUH ANAK DENGAN ATTENTION DEFICIT HYPERACTIVE DISORDERS ( ADHD)/HIPERAKTIF. Jurnal Kesehatan Al-Irsyad (JKA), Vol. 5. No. (1), Maret 2014
} 


\section{METODE PENELITIAN}

1. Penelitian ini menggunakan desian penelitian kualitatif. Penelitian kualitatif merupakan penelitian yang bermaksud untuk memahami fenomena tentang apa yang dialami subjek penelitian secara holestik dan dengan cara mendeskripsikan dalam bentuk kata-kata pada konteks ilmiah. Pendekatan ini digunakan untuk menghasilkan data deskripsi berupa kata-kata tertulis maupun lisan dari orangorang dan perilaku yang diamati. Pendekatan ini dilakukan guna mendapatkan data mendalam dengan teknik observasi, wawancara dan dokumentasi. ${ }^{10}$ Penelitian ini menelioti tentang peran orang tua dalam mengembangkan karakter anak dengan hiperaktif/ADHD. Pendekatan dalam penelitian ini menggunakan fenomenologi deskriptif. Fenomenologi deskriptif bertujuan untuk menggambarkan suatu fenomena dalam hal ini adalah tentang orang tua dalam mengembangkan karakter anak penderita hiperaktif/ADHD mempunyai keunikan dan perbedaan dari setiap individu. Melalui pendekatan fenomenologi ini diharapkan memperoleh gambaran pemahaman yang mendalam tentang pengalaman orang tua dalam mengembangkan karakter anak penderita ADHD.

2. Populasi merupakan wilayah generalisasi yang terdiri atas: obyek/subyek yang mempunyai kualitas dan karakteristik tertentu yang ditetapkan oleh peneliti untuk dipelajari dan kemudian ditarik kesimpulannya. Sedangkan untuk sampel merupakan bagian dari jumlah dan karakteristik yang dimiliki oleh populasi tersebut. Populasi pada penelitian ini yaitu orang tua anak penderita ADHD di (SLBN)Tebeng, Kota Bengkulu. dan sampel dari penelitian ini menggunakan 10 orang tua anak penderita ADHD (Attention Deficit Hyperactivity Disorder) yang mana akan dijadikan sampel untuk penelitian.

3. Teknik pengumpulan data dari penelitian ini menggunakan Teknik Nonprobability Sampling dimana Teknik pengumpulan sampel yang tidak memberi peluang/kesempatan sama bagi setiap unsur atau anggota populasi untuk dipilih menjadi sampel. Dan menggunakan sampel Jenuh dimana Teknik penentuan sampel dengan penentuan sampel bila semua anggota populasi

${ }^{10}$ Sugiyono, Metode Penelitian Kuantitatif, Kualitatif dan R\&D, ( Bandung: Alfabeta, 2018 ), hlm. 24 
digunakan sebagai sampel. Dilakuan bila jumlah populasi relative kecil, kurang dari 30 orang. ${ }^{11}$

Teknik pengumpulan data sebagai berikut:

a. Observasi

Seluruh aktivitas yang dilakukan dilapangan sesuai dengan masalah dan tujuan penelitian. Gunanya untuk mengumpulkan dan melengkapi data penelitian, seperti: alalamat penelitian di Kota Bengkulu, Provinsi Bengkulu. Serta observasi informasi mengenai berapa banyak anak penderita ADHD.

b. Wawancara

Wawancara yang digunakan yakni wawancara secara langsung kepada orang tua anak penderita hiperaktif/ADHD yang berjumlah 5 orang . Metode wawancara ini digunakan untuk mendapatkan data dari subyek penelitian.

c. Dokumentasi

Kelengkapan dari pengguna metode observasi dan wawancara dalam penelitian kualitatif. Terkait dengan penelitian yang dilaksanakan.

4. Instrumen dari penelitian ialah peneliti itu sendiri. Dimana peneliti kualitatif sebagai Human instrumen, berfungsi menetapkan fokus penelitian, memilih informan sebagai sumber data, melakukan pengumpulan data, menilai kualitas data, analisis data, menafsirkan data dan membuat kesimpulan atau temuannya. 12

5. Subyek penelitian ini sesuatu yang diteliti baik orang, benda, ataupun Lembaga (organisasi). Subyek dalam penelitian adalah orang tua anak penderita ADHD (Attention Deficit Hyperactivity Disorder). Lokasi dari penelitian ini di daerah Kota Bengkulu, serta lama penelitian 3 minggu.

\section{HASIL PENELITIAN DAN PEMBAHASAN}

Attention-Deficit Hyperactivity Disorder (ADHD) dapat disimpulka "Sebagai gangguan aktivitas dan perhatian "gangguan hiperkinetik adalah suatu gangguan psikiatrik yang cukup banyak ditemukan dengan gejala utama inatensi (kurang perhatian),

\footnotetext{
${ }^{11}$ Sugiyono, Metode Penelitian Kuantitatif, Kualitatif dan R\&D, ( Bandung: Alfabeta, 2018 ), hlm. 80

${ }^{12}$ Sugiyono.. Metode Penelitian Kualitatif. (Bandung: Alfabeta. 2009), hlm. 222-223
} 
hiperaktivitas, dan impulsivitas (bertindak tanpa dipikir) yang tidak konsisten dengan tingkat perkembangan anak, remaja, atau orang dewasa". Anak ADHD sering kali salah diartikan sebagai ADHD yang sering dianggap sama seperti anak yang memiliki karakter yang hamper mirip, misalnya dengan anak aktif, super aktif, autis, nakal, dll. Namun beberapa anak yang memiliki masalah konsentrasi dan perhatian tidak selalu terlalu aktif atau impulsif. Anak-anak jenis seperti ini digambarkan memiliki ADHD (AttentionDeficit Hyperactivity Disorder). Istilah tersebut yang diberikan sebagai gambaran tentang suatu kondisi medis yang mana telah disahkan secara internasional dimana mencakup disfungsi otak, dimana individu mengalami kesulitan dalam mengendalikan impuls, menghambat perilaku, dan tidak mendukung rentang perhatian aatau rentang perhatian tersebut mudah teralihkan. Hal-hal ini membuat anak ADHD akan menyebabkan sulit belajar, kesulitan berperilaku, kesulitan sosial, dan kesulitan lainnya yang saling berkaitan. ${ }^{13}$ ADHD didefinisikan sebagai berikut: a) Gangguan perilaku neurobiologis yang ditandai dengan tingkat instensi yang berkembang tidak sesuai dan bersifat kronis dan dalam beberapa kasus disertai hiperaktivitas. b) Gangguan biokimia kronis dan perkembangan neorologis yang mempengaruhi kemampuan seseorang untuk mengatur dan mencegah perilaku serta mempertahankan perhatian pada suatu tugas. c) Inefisiensi neorologis pada area otak yang mengontrol impuls dan pada pusat pengambilan keputusan (regulasi dan manajemen diri).

\section{KARAKTERSTIK ADHD}

Untuk lebih lengkap dan jelas terdapat beberapa karakteritik dari anak penderita ADHD (Attention-Deficit Hyperactivity Disorder) sebagai berikut ${ }^{14}$ :

a. Inatensi

1) Seringkali gagal memperhatikan baik-baik terhadap sesuatu yang mendetail.

2) Seringkali mengalami kesulitan memusatkan perhatian

3) Seringkali tidak mendengarkan jika diajak bicara secara langsung

4) Seringkali tidak mengikuti intruksi

5) Seringkali mengalami kesulitan dalam menjalankan tugas dan seringkali kehilangan barang/benda yang penting. 2006), hlm. 3

${ }^{13}$ Sugiarmin, M \& Baihaqi, M. Memahami dan membantu anak ADHD. (Bandung: PT Refika Aditama,

${ }^{14}$ MIF. Baihaqi. Memahami dan Membantu Anak ADHD. (Bandung: PT Refika Aditama, 2008). Hlm. 71 
b. Hiperaktif

1) Seringkali gelisah dengan tangan atau kaki mereka

2) Seringkali meninggalkan tempat duduk di rumah maupun di dalam kelas

3) Sering berlarian atau naik-naik secara berlebihan

4) Sering mengalami kesulitan dalam bermain

5) Sering "bergerak" atau "bertindak" seolah-olah dikendalikan oleh motor

6) Sering berbicara berlebihan

c. Impulsivitas

1) Mereka sering memberikan jawaban sebelum mendengarkan pertanyaan dengan selesai

2) Mereka sering mengalami kesulitan dalam hal bergiliran

3) Mereka sering menginterupsikan atau menggangu orang lain

\section{FAKTOR PENYEBAB}

Pada penderita ADHD (Attention-Deficit Hyperactivity Disorder) terdapat faktor-faktor yang menjadi penyebabnya, yaitu sebagai berikut ${ }^{15}$ :

a. Faktor genetik (keturunan), anak yang mempunyai orang tua menyandang ADHD memiliki delapan kali kemungkinan mempuny ai resiko mendapatkan anak penderita ADHD. Namun belum diketahui dari gen mana yang menyebabkan ADHD tersebut. Dari faktor keterunan sekitar $80 \%$ dari perbedaan antara anak-anak yang mempunyai gejala ADHD di dalam kehidupan masyarakat akan dipengaruhi oleh genetik.

b. Faktor fungsi otak, dalam sederhana bisa dikatakan bahwa secara biologis terdapat dua mekanisme di dalam otak yaitu pengaktifan sel-sel saraf (eksitasi) dan penghambat sel-sel saraf (inhibisi). Tampaknya pada ADHD perkembangan system ini lebih lambat, dan juga kapasitas yang lebih kecil. System penghambat dan pengereman di otak kurang bekerja dengan kuatatau kurang mencukupi.

c. Faktor lingkungan, dengan kata lain faktor lingkungan yang dimaksud dimana lingkup lingkungan yang secara luas, diaman lingkungan psikologis (relasi dengan orang lain, berbagai kejadian dan penanganan

\footnotetext{
${ }^{15}$ Kosasih, E. Cara Bijak Memahami Anak Berkebutuhan Khusus.(Bandung : Yrama Widya, 2012), hlm.
} 15. 
yang telah diberikan), lingkungan berupa fisik seperti (makanan, obatobatan dan menyinaran), lingkungan dari segi biologis (cedera otak, radang otak, komplikasi saat melahirkan.

\section{Peran Orang Tua}

a. Tetap Positif dan jaga Kesehatan

Orang tua berperan mengatur emosi dan Kesehatan fisik anak. Dimana hal ini menjadikan orang tua memiliki kendali atas banyak faktor yang dapat membuat secara positif mempengaruhi gejala gangguan pada anak. Dampak dari bersikap positif tersebut menjadikan aset terbaik bagi orang tua untuk membantu anak dengan penderita ADHD. Saat ini dengan kondisi orang tua yang tenang dan fokus, maka hal demikian lebih memungkinkan membuat orang tua untuk lebih terhubung dengan anak mereka untuk membantu agar anak tersebut menjadi tenang dan fokus.

1) Simpan segala sesuatu dengan perspektif. Dimana segala perilaku tidak menyenangkan yang ditunjukkan merupakan hal yang tidak disenggaja.

2) Tidak perlu memusingkan hal-hal kecil dan berkeinginan menjadikannya sempurna seperti yang lain.

3) Orang tua harus menanamkan kepercayaan terhadap anak mereka. Selalu pikirkan hal-hal positif, berharga dan unik yang dimiliki anak.

Hal yang positif yang diciptakan oleh orang tua akan memiliki dampak yang baik pula terhadap anak, dengan kata lain jika orang tua tersebut memiliki ketenangan dan fokus maka anak pun juga demikian.

b. Membangun Struktur dan Konsisten

Dimana terkait dengan anak penderita ADHD, mereka akan lebih lebih berhasil mengerjakan tugas Ketika tugas tersebut dalam pola yang dapat diprediksi dan di tempat yang diprediksi. Terkait dengan tuga orang tua membangun dan menciptakan dan mempertahankan struktur suasana rumah yang membuat anak akan mengerti apa yang mereka lakukan.

1) Ikuti rutinitas. 
Pentingnya dalam mengatur waktu dan tempat agar dapat membantu anak dengan penderita ADHD memahami dan mematuhi orang tuanya.

Sebagai orang tua juga bisa menetapkan kebiasaan sederhana yang memungkinkan untuk dilakukan seperti dalam hal makanan, kegiatan bermain, dan teempat tidur.

2) Gunakan jam dan timer

Orang tua harus mempertimbangkan menempatkan jam diseluruh ruangan bagian rumah. Dimana hal tersebut akan membuat anak akan memperingatkan anak tentang apa yang perlu dilakukan saat menunjukkan waktu tertentu.

3) Sederhanakan jadwal anak

Sebaiknya orang tua melakukan penyesuaian pada komitmen anak setelah mereka pulang sekolah dimana hal tersebut bisa diterapkan berdasarkan kemampuan setiap individu dan tuntutan kegiatan yang dijalankan.

4) Buatlah tempat yang tenang

Pastikan anak memiliki suatu ruang pribadi dimana yang tenang dan milikinya sendiri. Teras dan kamar tidur bisa menjadi salah satu contohnya.

5) Lakukan yang terbaik untuk menjadi rapi dan terorganisir

Bisa memastikan bahwa anak tahu dimana bahwa segala sesuatu ada tempatnya.

c. Tetapkan Harapan Dan Aturan Yang Jelas

Pada anak penderita ADHD membutuhkan aturan yang konsisten dimana yang dapat mereka pahami dan ikuti. Bisa dengan cara membuat aturan yang digantung di mana tempat anak tersebut dengan mudah membacanya. Penting juga kepada orang tua untuk menjelaskan bagaimana jika peraturan dipatuhi dan Ketika anak melanggar aturan tersebut. Orang tua harus konsisten terhadap aturan yang telah dibuat, ikuti dengan memberikan hadiah atau konsekuensi. Contoh dengan memberi hadiah kepada anak seperti memberi pujian, atau kegiatan, sama halnya bila 
diberikan konsekuensi seperti konsekuensi harus dijelaskan di muka dan terjadi segera setelah anak bertingkah buruk.

\section{d. Anjurkan Betgerak Dan Tidur}

Dimana anak-anak penderita ADHD sering memiliki energi yang berlebihan. Temukan olahraga yang diminati oleh anak seperti softball dan olahraga dengan individua tau tim seperti basket dll. Masalah dan gangguan pada penderita ADHD membuat stimulus dan berlebihan dan kesulitan tertidur. Dimana peran orang tua bisa membantu anak dengan mengurangi waktu menonton televisi, buat waktu senggang untuk menurunkan level aktivitas untuk sekitar satu jam sebelum tidur, Seperti mewarnai, menggambar dan bercerita dengan tenang dan fokus.

e. Bantu Anak Makan Dengan Benar

Anak-anak penderita ADHD dikenal dengan makan yang tidak teratur. Cegah kebiasaan makan yang tidak teratur dan tidak sehat dengan menjadwalkan makan makanan yang bergizi atau cemilan yang sehat untuk anak. Atur makanan anak dengan menyingkirkan makanan yang cepat saji di rumah, membatasi makanan yang berlemak dan berikan suplemen vitamin makanan.

f. Ajari Anak Cara Berteman

Sulit bagi anak-anak penderita ADHD untuk belajar keterampilan sosial dan aturan sosial. Hal ini membuat peran orang tua menjadi pendengar yang lebih baik, belajar membaca wajah orang dan juga Bahasa tubuh dan lebih banyak berinteraksi dalam kelompok. Bisa dengan memulai berhatihati memilih teman bermain untuk anak dengan Bahasa keterampilan fisik yang mirip.

\section{Yang Dilakukan Orang Tua}

Dari hasil penelitian yang dilakukan oleh peneliti ditemukan bahwa orang tua memiliki peran yang khusus dalam bagaimana untuk mengembangkan karakter anak penderita ADHD. Dalam wawancara penulis dengan orang tua anak penderita ADHD, ibu Elmi dalam wawancaranya mengatakan bahwa ${ }^{16}$ :

${ }^{16}$ Wawancara dengan bu Elmi, tanggal 23 November 2021, pukul jam 08:15 WIB 
"Saya sudah belajar dikit demi sedikit dalam mengembangkan dan mengontrol perilaku anak saya dimana tidak bisa berdiam terlalu lama, dengan mengontrol makanan yang sehat seperti telor menjadi makanan kesukaan. Sulit untuk fokus terhadap satu hal dan mudah marah karena kalau menginginkan sesuatu itu dia harus dapat sesuai dengan keinginan. Kalau anak saya tidak terlalu sering saya biarkan terlalu lama diluar rumah karena takutnya berlarian tanpa arah berhubung keadaan rumah di pinggir jalan raya ya jadi takut, jadi membiasakan dia untuk tidak terlau lama dalam hal bermain di luar rumah”.

Dalam hal untuk menghadapi anak penderita ADHD cukup sulit dibandingkan dengan anak lainnya. Hal ini disampaikan oleh bu Eni dalam wawancaranya bahwa ${ }^{17}$ :

"memiliki anak penderita ADHD juga menjadi suatu tantangan bagi saya dalam hal mengontrol emosi jika anak saya tidak bisa diam di satu tempat dan kadang menganggu teman-teman yang lain ingin bermain. Saya mengajarkan kalau mau bermain dengan teman jangan buat keributan dan belajar untuk bagaimana bisa duduk dengan tenang jika Bersama teman-teman mainnya".

Kondisi dimana anak penderita ADHD sulit untuk diatur oleh dirinya maupun orang tua pun juga dialami oleh ibu Ariyana dalam wawancaranya bahwa $^{18}$ :

"awal dalam membiasakan dengan perilaku anak saya mengalami kesulitan dimana apapun yang saya katakana dia membantah dan mudah menanggis, makan pun tidak teratur namun semakin karena kebiasaan saya control lama-lama hal tersebut bisa dikurangi walaupun tidak bisa sepenuhnya"

Dalam hal pembiasaan pada anak penderita ADHD akan membuat anak mengalami perubahan yang positif, hal ini dalam wawancara oleh ibu Gea dalam wawancaranya bahwa ${ }^{19}$ :

"cara saya untuk membuat anak lebih terkontrol perilakunya dengan kebiasaan untuk tidur siang dan jam makan yang teratur, saya juga berusaha untuk tidak emosi dalam menghadapi situasi perilaku anak saya tersebut".

Kelebihan anak penderita ADHD itu lebih menonjol dibandingkan dengan yang lainnya dan bisa untuk dikontrol dengan orang tau juga, yang dikatakan oleh bu Andini dalam wawancaranya bahwa ${ }^{20}$ :

"Saya dengan memiliki anak ADHD tidak malu ya, karena menurut say itu dia pasti ada kelebihan tersendirinya, akhir-akhir ini lebih sering

\footnotetext{
${ }^{17}$ Wawancara dengan bu Eni, tanggal 23 November 2021, pukul 09.00 WIB

${ }^{18}$ Wawancara dengan bu Ariyana, tanggal 24 November, pukul 08:00 WIB

${ }^{19}$ Wawancara dengan bu Gea, tanggal 24 November 2021, pukul 08:30 WIB

${ }^{20}$ Wawancara dengan bu Andini, tanggal 25 November, pukul 09:00 WIB
} 
berbicara dalam Bahasa inggris juga dan daya ingat sesuatu itu juga lebih dari pada yang lainnya".

\section{SIMPULAN}

Dalam hal mengembangkan karakter anak penderita ADHD bagi orang tua bukanlah suatu hal yang mudah, terlebih dari karakter yang terlalu hiperaktif (sulit mengendalikan gerakan), intensi (sulit memusatkan perhatian), impulsivitas (sulit Menahan keinginan). Selain itu terdapat beberapa faktor dari penderita anak ADHD yaitu bisa faktor dari genetic (keturunan), faktor fungsi otak dan juga faktor lingkungan. Banyak hal yang dapat dilakukan oleh orang tua dalam berperan mengembangkan karakter anak penderita diantara melalui menjaga Kesehatan dan lebih mengontrol emosi dalam menghadapi anak ADHD, pembiasaan menjaga pola makan, mengatur jam tidur dan bermain, membuat kebiasaan yang positif untuk dilakukan, menciptakan aktivitas olahraga yang disukai anak tersebut dan mengajarkan dalam hal memilih teman-teman yang sama seperti fisiknya.serta metode yang digunakan dalam penelitian ini adalah Kualitatif dengan fenomenologi deskriptif,

\section{DAFTAR PUSTAKA}

A. Dayu P, Mendidik Anak ADHD . Jogjakarta: Javalitera, 2014.

Ahmad Subandi \& Rusana, "Pengalaman Orang Tua Dalam Mengasuh Anak Dengan Attention Deficit Hyperactive Disorders (ADHD)/Hiperaktif", dalam Jurnal Kesehatan Al-Irsyad (JKA), Vol. 5. No. 1, Maret 2014

Baihaqi, M \& Sugiarman, M. Memahami dan membantu anak ADHD. Bandung: Refika Aditama, 2006

Hidayati, E.Peran pendampingan regulasi emosi terhadap perilaku maltreatment pada ibu dari anak $G P P / H$. Jurnal Humanitas. 2013

John W. Santrock. Perkembangan Anak, Jilid 2. Jakarta: Erlangga. 2007

Kosasih, E. Cara Bijak Memahami Anak Berkebutuhan Khusus, Bandung : Yrama Widya, 2012 MIF. Baihaqi. Memahami dan Membantu Anak ADHD. Bandung: Refika Aditama, 2008

Ratih Dwilestari Puji Utami, Wahyuningsih Safitri , Christiani Bumi Pangesti3, \& Nur Rakhmawati, "Pengalaman Orang Tua Dalam Merawat Anak Dengan Attetion Deficit 
Hyperectivity Disorder (ADHD)", dalam Jurnal Kesehatan Kusuma Husada, Vol. 12, No. 2, Juli 2021

Sugiyono, Metode Penelitian Kuantitatif, Kualitatif dan R\&D, Bandung: Alfabeta, 2018

Sugiarmin, M \& Baihaqi, M. Memahami dan membantu anak ADHD. Bandung: Refika Aditama, 2006

Wimbarti S \& Rahmi, I., "Inhibition in ADHD and non-ADHD children ages 6-12 years", dalam Internationl Journal of Research Studies in Psychology, Vol. 7, No. 1, 2018 